\title{
STUDIES ON SIGNIFICANT ASPECTS OF NEISSERIA MUCOSA IN CLINICAL MICROBIOLOGY
}

\author{
Mane R. $S^{1,}$ Ghare V. $S^{2}$ \\ Dept. of Microbiology and Biotechnology, Karnatak University, Dharwad, India \\ Dept.of Microbiology,S.B.B Alias Appasaheb Jedhe College of Arts, Commerce \&Science,Pune, India
}

rohitmane2025@gmail.com

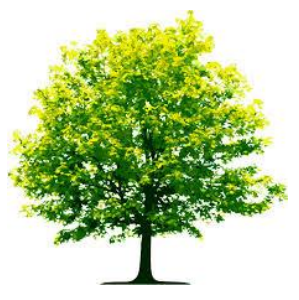

Keywords: Neissera mисоsa, review.

\begin{abstract}
A B S T R A C T
The current advances in cellular microbiology, genomics, and immunology has opened novel horizons in the considerate of neisserial pathogenesis and in the definition of novel prophylactic involvement. It is now clear that Neissera mucosa has evolved a number of surface structures to mediate communication with host cells and a numeral of mechanisms to undermine the immune system and escape complement-mediated killing. In this review, we revealed significant aspects of Neissera mucosa for readers.
\end{abstract}

Citation: Mane R. S, Ghare V. S(2018). Studies On Significant Aspects Of Neisseria Mucosa In Clinical Microbiology. International Journal of Advanced Multidisciplinary Scientific Research (IJAMSR ) ISSN:2581-4281 Vol 1, Issue 9, November, 2018, \#Art.916, pp 55-57
Introduction

Neisseria mucosa was described by von Lingelsheim in 1906. One year later 1960s, Berger and coworkers showed that Neisseria mucosa may be differentiated from the N. sicca, N. subflava biovar perflava by a nitrate reduction test. There are no biochemical methods for differentiating between these latter species $[1,4]$
Berger and coworkers showed that N. subflava biovar perflava and N. sicca were serologically distinct $[2,3,6]$.

Neisseria mucosa belongs to the family Neisseriaceae. It is clinically important pathogenic bacteria and is relatively easy to identify from other Neisserial species $[1,2,6]$. The other species of Neisseria such as $\mathrm{N}$. lactamica and $\mathrm{N}$. cinerea are commonly painstaking 


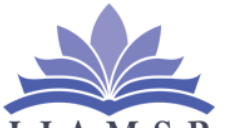

I J A M S R

\section{International Journal of}

Advanced Multidisciplinary Scientific Research (IJAMSR) ISSN:2581-4281

commensals, but have been alarmed as causes of infection in patients who are immunocompromised. More up to date species to the genus Neisseria are N. oralis, N. shayeganii, N. wadsworthii, N. zoodegmatis and N. animaloris isolated from human clinical samples $[1,2,3,6]$.

\section{Taxonomy $[1,2,3$,}

Phylum: - Proteobacteria

Class: - Betaproteobacteria

Order: - Neisseriales

Family: - Neisseriaceae

Genus: - Neisseria

Species: - mucosa

\section{Media for Isolation $[1,2,3,4,5]$}

Non- Selective media:

a) Blood agar

b) Chocolate agar

c) Muller Hinton starch casein Hydrolysate agar

\section{Selective Media}

a) GC selective agar

b) Modified T-M agar

\section{Incubation Conditions}

$5-10 \% \mathrm{CO}_{2}$ at $37 \pm 2^{\circ} \mathrm{C}, 24 \mathrm{hrs}-48 \mathrm{hrs}$.

\section{Morphological appearance}

Neisseria mисоsa shows adherent colonial morphology, pigmented or non-pigmented and opaque $[1,2,5,6]$. However, they form smooth, round, moist, or uniform gray/brown/red colonies with a greenish color underneath on primary isolation medium. It is gram negative, non motile, non spore forming bacteria $[3,4]$.

\section{Biochemical appearance}

Neisseria mисова shows positive results for Oxidase, Catalase, chitinase, iodine, carbonic anhydrate test, nitrite and nitrate production, Sugar fermentation tests (Fructose, Glucose, Maltose and Sucrose) [4,5,6] while they show negative results for acid production from Lactose and Mannose, Beta- galactosidase, Gamma glutamyl transferase and tributyrin hydrolysis $[4,5,6]$.

\section{Chemistry Of Neisseria Mucosa}

Neisseria mucosa is a part of normal human nasopharyngeal flora and infrequently causes human infections, including meningitis, cerebrospinal fluid shunt infection $[1,2,3,4,5,6]$.

Neisseria mucosa LPS consists of lipid A, a central part containing two 2-keto-3-deoxy-octulosonic acids (KDO) and two heptoses (L-glycero-D-manno-heptopyranoside) substituted with short polysaccharide side chains. Due to the short polysaccharide side chains and lack of repeating $\mathrm{O}$ antigen units, meningococcal LPS is frequently referred to as lipo-oligosaccharide (LOS). The inherited basis for synthesis, structure, and function of meningococcal LPS has recently been thoroughly reviewed $[3,4,6]$. 


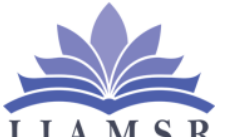

\section{Advanced Multidisciplinary Scientific Research (IJAMSR) ISSN:2581-4281}

Purified Neisseria mucosa LPS forms huge complexes in aqueous solution [6]. In cells expressing CD14 (monocytes, macrophages, neutrophils), better LPS aggregates come into view to have lesser cell-activating potency than lesser sized aggregates. The capsule polysaccharide does not affect the activation of these cells $[4,5]$. In endothelial cells, which are dependent on soluble CD14 for LPS-induced activation, the size of the aggregates does not influence cell activation, whereas capsular polysaccharide reduces the activation $[2,4,8]$.

\section{Conclusion}

One can use and aim for the clinical research on Neisseria mucosa by using the present review article.

\section{References}

1) Euzeby, JP. List of Prokaryotic names with Standing in Nomenclature - Genus Neisseria. 2013.

2) Holt JG. Bergey's Manual of Determinative Bacteriology. In: Holt JG, Krieg NR, Sneath PHA, Staley JT, Williams ST, editors. 9th ed. Baltimore: Williams and Wilkins; 1994. p. 34-540.

3) Grant PE, Brenner DJ, Steigerwalt $A G$, Hollis DG, Weaver RE. Neisseria elongata subsp. nitroreducens subsp. nov., formerly CDC group M-6, a gram-negative bacterium associated with endocarditis. $J$ Clin Microbiol 1990; 28: 2591-6.

4) Mane RS, Patil GS, Choradiya BR. (2018). Acidic Chitinase production by Neisseria species. World Journal of Pharmaceutical Research. 7 (7). 2081- 2086.

5) Musher DM. Haemophilus Species. In: Baron S, editor. Medical Microbiology. 4th edition. Galveston (TX): University of Texas Medical Branch at Galveston; 1996.
Chapter 30. Available from:

http://www.ncbi.nlm.nih.gov/books/NBK84 $58 /$

6) Veron M, Lenvoise-Furet A, Coustere C, Ged C, Grimont F. Relatedness of three species of "false neisseriae," Neisseria caviae, Neisseria cuniculi, and Neisseria ovis, by DNA-DNA hybridizations and fatty acid analysis. Int J Syst Bacteriol 1993; 43: 210-20. 